\title{
Pengaruh Teknik Klarifikasi Nilai terhadap Minat dan Prestasi Belajar IPS
}

\author{
Made Sujana ${ }^{1}$, I W. Lasmawan ${ }^{2}$ \\ ${ }^{1,2}$ Program Studi Pendidikan Dasar, Program Pascasarjana \\ Universitas Pendidikan Ganesha \\ Singaraja, Indonesia \\ e-mail: made.sujana@pasca.undiksha.ac.id ${ }^{1}$, wayan.lasmawan@pasca.undiksha.ac.id ${ }^{2}$,
}

\begin{abstract}
Abstrak
Penelitian ini bertujuan untuk mengetahui pengaruh teknik klarifikasi nilai terhadap minat belajar dan hasil belajar IPS pada siswa kelas VI SD. Rancangan penelitian ini menggunakan pola dasar The Posttest Only Control Group dengan jenis eksperimen semu. Sampel penelitian berjumlah 80 siswa. Data yang dikumpulkan adalah minat belajar dan hasil belajar IPS. Data dianalisis dengan menggunakan MANOVA berbantuan SPSS 17.00 for windows. Hasil Penelitian menunjukkan bahwa: Pertama, minat belajar siswa yang mengikuti teknik klarifikasi nilai secara signifikan lebih baik daripada siswa yang mengikuti pembelajaran dengan pembelajaran konvensional $(F=60,474 ; p<0,05)$. Kedua, hasil belajar IPS siswa yang mengikuti teknik klarifikasi nilai secara signifikan lebih baik daripada siswa yang mengikuti pembelajaran dengan pembelajaran konvensional $(F=18,344 ; p<0,05)$. Ketiga, secara simultan minat belajar dan hasil belajar IPS antara siswa yang mengikuti teknik klarifikasi nilai secara signifikan lebih baik daripada siswa yang mengikuti pembelajaran konvensional.
\end{abstract}

Kata kunci: Teknik Klarifikasi Nilai, Minat Belajar, Hasil Belajar IPS

\begin{abstract}
This study aim to determine influence Clarification Value Technique toward learning interest and social learning outcomes for sixth grader elementary school student. It design using the post test only control group with quassy experiment type. The data analyzed using MANOVA with helped with SPSS 17.00 for windows. The result indicated that : first, student learning interest that followed the clarification value technique were significantly better than student with conventional learning. $(F=60,474 ; p<0,05)$. Second, student Social learning outcomes that followed the clarification value technique were significantly better than student with conventional learning. $(F=18,344 ; p<0,05)$. Third, simoultaneusly, learning interest and social learning outcomes between student with Clarification Value Technique were significantly better than student with conventional learning.
\end{abstract}

Keywords: Clarification Value Technique, Learning Interest, Social Learning Outcomes Ability 


\section{Pendahuluan}

Berbicara pendidikan di Indonesia tidak terlepas dari Pendidikan Nasional yang seringkali menjadi perbincangan. Pendidikan Nasional sebagai suatu organisasi haruslah bersifat dinamis, dan fleksibel. Jika demikian halnya maka pendidikan bukan hanya sekedar pengemban kebudayaan, melainkan juga sebagai pengembang kebudayaan termasuk pengubah kebudayaan (Sumantri, 2001:51). Karenanya, pendidikan juga dapat menyerap perubahan-perubahan yang cepat antara lain karena perkembangan ilmu dan teknologi, perubahan masyarakat menuju kepada masyarakat yang semakin demokratis dan menghormati hak-hak asasi manusia .

Pembelajaran yang bermakna menempatkan siswa sebagai subjek aktif bukan sebagai objek sehingga para siswa mampu menjadi inovator-inovator yang handal dan mampu bersaing di dunia global. Agar pendidikan mampu mencapai harapan tersebut, maka cara dan isi pendidikan harus dipolakan sedemikian rupa sehingga dapat menimbulkan dan mendorong hasrat untuk kemajuan, hasrat pembaharuan, perubahan, inisiatif, adaptasi serta kapasitas dan hasrat untuk belajar terus-menerus (Sindunata; 2001,20).

Namun, realitasnya banyak sekali fakta-fakta yang menunjukkan adanya gap (kesenjangan) yang ditimbulkan dari dunia pendidikan dan pembelajaran yang di harapkan. Wajar jika kita mengatakan bahwa pembelajaran tidak lain dari upaya pelestarian kebudayaan diam atau bisu yang menempatkan siswa sebagai objek pendidikan dan pelestarian privilegeprivilege khusus dan istimewa, serta status quo di pihak guru sebagai subjek pendidikan sekaligus sebagai figur kelompok elite sosial politik sehingga pendidikan bukan lagi sebagai upaya pencerdasan kehidupan bangsa agar mampu mengenal realitas diri dan lingkungannya secara tepat dan jitu melainkan suatu upaya pembutaan kesadaran yang disengaja dan terencana (Sindunata; 2001,20). Akhirnya pendidikan tidak ubahnya sebagai sistem yang kaku serta mematikan partisipasi masyarakat, inisiatif, dan kreatifitas siswa dan guru tidak mungkin melahirkan iklim atau proses pendidikan yang demokratis (Tilaar,2002:68)

Pendidikan karenanya, semacam aktifitas penindasan. Artinya pendidikan smata-mata merupakan tindakan menundukkan siswa, dimana siswa ibarat alat perekam sehingga pembelajaran bukan merupakan proses menumbuhkan dan mengembangkan kesadaran siswa. Padahal esensi dari pendidikan adalah usaha sadar dan terus menerus oleh manusia dalam menyelaraskan kepribadiannya dengan keyakinan dan nilai-nilai yang beredar dan berlaku dalam masyarakat berikut kebudayaanya (Murtiningsih ;2004,1) Jika demikian halnya pendidikan di Indonesia masih diwarnai saratnya kepentingan, sehingga berdampak terbawanya kualitas pendidikan di Indonesia pada satu titik yang sangat memprihatinkan.

Beranjak dari hal tersebut, maka pembelajaran IPS akan lebih bermakna, pembelajaran yang bermakna akan membawa siswa pada pengalaman belajar yang mengesankan. Pengalaman yang diperoleh siswa akan semakin berkesan apabila proses pembelajaran yang diperolehnya merupakan hasil dari pemahaman dan penemuannya sendiri. Dalam konteks ini siswa mengalami dan melakukannya sendiri. Proses pembelajaran yang berlangsung melibatkan siswa sepenuhnya untuk merumuskan sendiri suatu konsep. Keterlibatan guru hanya sebagai fasilitator dan moderator dalam proses pembelajaran tersebut. Jadi Bagaimana memperkenalkan siswa terhadap dunianya dalam pendidikan sehingga tumbuh kesadaran dan akhirnya memiliki seperangkat ketermpilan sosial untuk menyelesaikan masalah-masalah masyarakat maka sesunggunya inilah esensi dari pembelajaran IPS. Disisi lain pembelajaran IPS juga berorientasi pada tingkah laku para siswa yaitu, 1. Pengetahuan dan pemahaman, 2. Sikap hidup belajar, 3. Nilai-nilai sosial, 4. Keterampilan (Hamalik, 1992:40-41).

Kurikulum yang diyakini sebagai komponen vital dan strategis dalam keseluruhan sistem pendidikan, juga belum menjadi instrumen efektif bagi terwujudnya pendidikan nasional yang ideal, karena masih kental dengan "content oriented" yang berbasis keilmuan Kondisi ini menyebabkan pembelajaran IPS tidak mengikuti alur pendekatan proses pengambilan keputusan dan pemecahaan masalah sehingga memposisikan guru sebagai satu-satunya sumber belajar yang bermuara pada vakumnya proses pembelajaran.

Sementara disatu pihak kita juga dihadapkan pada revolusi komunikasi sebagai salah satu dampak dari globalisasi telah menghadirkan seperangkat permasalahan dan sekaligus tantangan bagi dunia pendidikan, khususnya pendidikan IPS pada jenjang Sekolah Dasar untuk dapat menjadikan siswa sebagai manusia yang berkompetensi global namun tetap berwawasan budaya kebangsaan, sehingga diperlukan seperangkat upaya strategis untuk mewujudkannya (Abijhani, 2006; Farisi, 2006). 
Pembelajaran IPS disekolah-sekolah diharapkan menjadikan siswa memperoleh pengetahuan , keterampilan , sikap dan kepekaan untuk menghadapi hidup dengan tantangantantangannya. Selanjutnya diharapkan pula mereka kelak mampu bertindak secara rasional dalam memecahkan masalah-masalah yang dihadapi. Perlu disadari bahwa dunia sekarang telah mengalami perubahan-perubahan yang amat cepat dalam segala bidang. Karenanya, dibutuhkan kompetensi yang handal untuk menghadapi hal tersebut. Kompetensi itu akan dapat terwujud jika dalam setiap pembelajaran IPS dilakukan upaya menumbuhkembangkan kesadaran siswa bahwa sesungguhnya kita akan berhadapan dengan kehidupan yang penuh harapan dan juga tantangan yang bermuara pada datangnya beragam pilihan dimana kita harus menentukan pilihan dengan segala konsekuensinya. Karenaya, melalui pembelajaran IPS siswa akan dipersiapkan dalam memahami dan mengamalkan nilai-nilai dasar yang diperlukan untuk hidup secara mapan di masyarakat.

Jika hal tersebut dapat terlaksana dalam pembelajaran IPS, maka anggapan pembelajaran IPS adalah menyangkut materi hapalan, bersifat kaku, teoritis yang akhirnya bermuara pada rasa membosankan siswa yang mengkristal di benak siswa dan masyarakat secara perlahan-lahan akan berkurang bahkan hilang. Namun harapan tersebut tinggal harapan, karena kenyataan di lapangan pembelajaran IPS belum menunjukkan ke arah pembelajaran yang bermakna. Telah banyak dibicarakan mengenai kurang berpungsinya IPS dalam memecahkan berbagai permasalahan di Indonesia, IPS seakan tidak berdaya menghadapi setumpuk permasalahan dari kenakalan remaja sampai pada teori pembangunan nasional (Surias Sumantri, 1986 : 115).

Kondisi tersebut semakin meyakinkan ketika para pendidik masih perlu penyesuaian dengan KTSP, para guru sendiri belum siap dengan kondisi yang sedemikian plural sehingga untuk mendesain pembelajaran yang bermakna masih kesulitan. Sistem pembelajaran duduk tenang, mendengarkan informasi dari guru sepertinya sudah membudaya sejak dulu, sehingga untuk mengadakan perubahan ke arah pembelajaran yang aktif ,kreatif, menyenangkan agak terhambat namun belum terlambat. Pembelajaran IPS dengan roh lama sudah seharusnya tinggalkan menuju pembelajaran aplikatif terhadap kebutuhan siswa dan masyarakat.

Salah satu pendekatan pembelajaran pengetahuan sosial yang dapat memfasilitasi dan menumbuhkembangkan kompetensi akademik, keterampilan sosial, dan keterampilan berkomunikasi berdasarkan karakteristik nilai-nilai masyarakat setempat adalah pendekatan sosial - budaya (Converta, 2007). Mereka merekomendasikan model pengorganisasian materi IPS dengan basis nilai sosial dan karakteristik budaya, yaitu: (1) mengakomodir nilai-nilai budaya setempat, (2) berisikan pemahaman terhadap etos dan bentuk budaya lokal, (3) memediasi pengembangan keterampilan budaya berpikir, (4) berorientasi pada idiologi negara, dan (5) mengandung muatan pesan moral dan transformasi nilai-nilai sosial aktual.

Berdasarkan seperangkat permasalahan diatas, maka penelitian ini diarahkan pada Pengaruh model pembelajaran berbasis sosial budaya terhadap prestasi belajar dan literasi sosial budaya siswa dalam pembelajaran IPS. Model pembelajaran ini diyakini dapat menjembatani kebutuhan belajar siswa karena dalam proses pembelajaran akan selalu bersandar pada keluhuran nilai-nilai sosial dan karakteristik budaya masyarakat setempat.

Telah banyak studi yang dilakukan mengenai model pembelajaran IPS, namun model pembelajaran yang berbasis sosial-budaya, belum banyak yang melakukannya. Apalagi yang bertalian dengan karakteristik kurikulum 2006 yang memberi penekanan pada penghargaan dan akomodasi potensi lokal, khususnya budaya masyarakat setempat. Berdasarkan rasional tersebut, maka model pembelajaran IPS - SD yang berorientasi pada nilai-nilai sosial dan budaya merupakan kebutuhan yang mendesak untuk dilakukan, bila mengacu pada semangat dan tujuan dari pemberlakuan kurikulum 2006.

Melalui Pembelajaran berbasis sosial budaya menempatkan siswa pada posisi strategis dalam proses pembelajaran, dan guru sebagai perancang dan pelaksana pembelajaran yang handal dan kreatif. Siswa dalam pembelajaran berbasis budaya diakui dan dihargai sebagai individu dengan latar belakang, pengalaman, dan pengetahuan awal yang unik, yang memiliki kemampuan dan keinginan untuk belajar, dan untuk menjadi kreatif berdasarkan kaidah ilmiah dalam konteks komunitas budayanya. Dengan kata lain pembelajaran berbasis sosial budaya menjadikan siswa sejak dini telah dikondisikan dan difasilitasi untuk mengenal, memahami, dan memahiri nilai-nilai sosial dan budaya masyarakatnya, sehingga mereka dapat berpikir, bersikap, dan berperilaku berdasarkan nilai-nilai budaya dalam melakoni kehidupan global, nasional maupunl yang semakin dinamis.

Tujuan penelitian ini adalah: (1) untuk mengetahui perbedaan minat antara siswa yang mengikuti pembelajaran teknik klarifikasi nilai dengan model pembelajaran konvensioal.; (2) 
untuk mengetahui perbedaan prestasi belajar IPS antara siswa yang mengikuti pembelajaran teknik klarifikasi nilai dengan model pembelajaran konvensional.; (3) untuk mengetahui secara simultan, perbedaan minat dan prestasi belajar IPS antara siswa yang mengikuti pembelajaran teknik klarifikasi nilai dengan model pembelajaran konvensioanal.

\section{Metode}

Penelitian ini menggunakan metode penelitian eksperimen, menurut Sugiyono (2006:109) mengemukakan bahwa penelitian eksperimen merupakan metode penelitian yang digunakan untuk mencari pengaruh perlakuan tertentu terhadap yang lain dalam kondisi yang terkendali. Sugiyono juga menyatakan ciri utama dari penelitian eksperimen adalah variabel kontrol dan pemberian perlakuan terhadap kelompok eksperimen. Ada berbagai variasi dari penelitian eksperimen, dan pada penelitian ini menggunakan jenis penelitian eksperimen semu atau eksperimen kuasi, hal ini dilihat dari subjek eksperimen yang tidak dirandomisasi untuk menentukan sampel guna ditempatkan dalam kelompok eksperimen dan kelompok kontrol. Dengan pola dasar "The Posttest-Only Control-Group Desain" yang mana polanya dapat dilihat pada rancangan di bawah ini.

\begin{tabular}{|lll|}
\hline$E$ & $X$ & $O 1$ \\
$K$ & & O2 \\
& - & O1 \\
\hline
\end{tabular}

Gambar 1. Rancangan Eksperimen The posttest-Only Control Group Desain

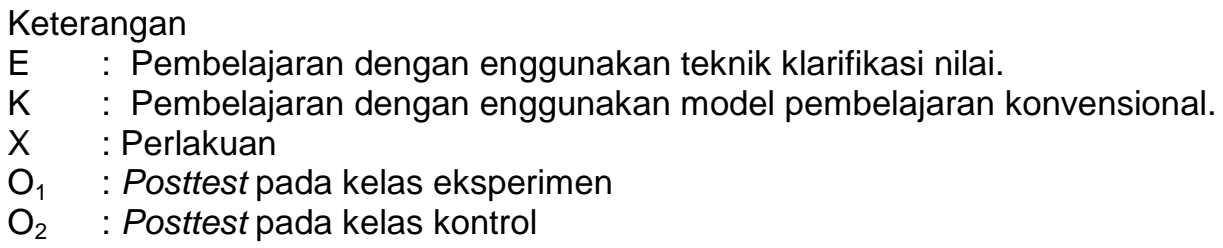

Populasi dalam penelitian ini adalah siswa kelas VI SD Gugus VI Kecamatan Sawan Kabupaten Buleleng yang berjumlah 207 orang. Teknik yang digunakan dalam pengambilan sampel ini adalah teknik sampling. Dalam penelitian ini teknik sampling yang digunakan adalah random sampling. Teknik ini dilakukan dengan mengambil dua kelas secara acak. Pengambilan dua kelas secara acak dilakukan setelah melakukan uji kesetaraan terhadap seluruh kelas terlebih dahulu. Uji kesetaraan yang dilakukan menggunakan bantuan SPSS 17.0 for windows dengan signifikansi $5 \%$. Jika angka signifikansi hitung kurang dari 0,05 maka kelas tersebut tidak setara. Sedangkan jika angka signifikansi hitung lebih besar dari 0,05 maka kelas tersebut setara.

Berdasarkan data hasil uji kesetaraan tersebut, maka dapat diambil kesimpulan bahwa siswa siswa kelas VI SD Gugus VI Kecamatan Sawan Kabupaten Buleleng memiliki kemampuan yang setara, karena memiliki nilai signifikansi $>0,05$. Dalam menunjuk kelas eksperimen dan kelas kontrol, peneliti melakukan sistem undian. Jika dalam undian didapatkan hasil kelas VI A SD 1 Sangsit dengan kelaVI SD 4 Sangsit sebagai sampel penelitian, maka hasil tersebut ditolak, dan dilakukan pengundian ulang. Hal itu dikarenakan kemampuan dua kelas tersebut tidak setara. Berdasarkan sistem undian yang telah dilakukan, dapat disimpulkan bahwa kelas VI B SD 1 Sangsit sebagai kelompok eksperimen dan dengan kelaVI SD 8 Sangsit sebagai kelompok control.

Pada penelitian ini yang termasuk variabel bebas adalah faktor yang sengaja dimunculkan, dimanipulasikan, dan diukur oleh penelitian dan dikenakan kepada kelompok eksperimen yang diteliti. Sebagai variabel bebas dalam penelitian ini adalah penerapan teknik klarifikasi nilai. Variabel terikat adalah variabel atau faktor yang diobservasi dan diukur untuk melihat pengaruh variabel bebas terhadap subjek yang dikenai perlakuan. Pada penelitian ini, yang termasuk variabel terikat adalah minat belajar dan hasil belajar IPS.

Dalam penelitian ini data yang akan dikumpulkan adalah data minat belajar IPS siswa dan hasil belajar IPS siswa. Data minat belajar IPS siswa dikumpulkan dengan metode angket 
yaitu kuesioner minat dan data hasil belajar IPS siswa dikumpuklan dengan metode tes yaitu tes pilihan ganda.

Untuk Instrumen-instrumen yang disusun sebelum digunakan untuk mengambil data penelitian terlebih dahulu diuji coba, uji coba dilakukan terhadap minat belajar siswa dan tes hasil belajar siswa dalam pembelajaran IPS SD. Instrumen minat belajar dibuat berdasarkan kisi-kisi. Instrumen yang dibuat kemudian dikonsultasikan dengan ahli. Selanjutnya instrumen tersebut diuji validitasnya. Uji coba tes hasil belajar IPS memperhatikan beberapa aspek, yaitu validitas isi, validitas butir, reliabilitas tes, daya beda dan tingkat kesukaran tes.

Data yang telah diperoleh dari penelitian dideskripsikan menurut masing-masing variabel. Masing-masing kelompok data tersebut akan dicari harga rerata (M), standar deviasi (SD), modus (Mo), median (Me) setiap kelompok yang diteliti. Untuk kualifikasi pendeskripsian data minat belajar dan hasil belajar yang diperoleh siswa menggunakan kriteria norma kerangka teoretik kurva ideal.

Pengujian prasyarat analisis dilakukan untuk mengikuti apakah data yang tersedia dapat dianalisis dengan statistic parametric atau tidak. Pengujian persyaratan analisis yang dilakukan adalah uji normalitas dan uji homogenesis. Pengujian normalitas dilakukan untuk meyakinkan bahwa sampel berasal dari populasi yang berdistribusi normal, sehingga uji hipotesis dapat dilakukan. Uji normalitas data dilakukan pada empat kelompok data. Kelompok pertama adalah minat belajar dalam pembelajaran pada mata pelajaran IPS yang mengikuti Teknik Klarifikasi Nilai, kelompok kedua adalah minat belajar dalam pembelajaran pada mata pelajaran IPS yang mengikuti model konvensional, kelompok ketiga data prestasi belajar siswa pada pelajaran IPS yang mengikuti Teknik Klarifikasi Nilai dan kelompok keempat data prestasi belajar siswa pada mata pelajaran IPS yang mengikuti model konvensional.

UJi normalitas pada keempat kelompok data menggunakan SPSS-17.00 for windows uji statistik Kolmonogov-smirnov pada signifikansi 0,05. Uji ini dilakukan terhadap data post test, perubahan skor postes terhadap kelompok eksperimen dan kelompok control.

Uji homogenitas dimaksudkan untuk memperlihatkan bahwa dua atau lebih kelompok data sampel berasal dari populasi yang memiliki variansi yang sama. Pengujian homogenitas dilakukan dengan uji kesamaan varian-kovarian menggunakan SPSS-17.00 for windows melalui uji Box's $M$ untuk uji homogenitas secara bersama-sama dan dengan uji levene's untuk uji homogenitas secara terpisah. Kriteria pengujian data memiliki matriks varians-kovarian yang sama (homogen) jika signifikansi yang dihasilkan dalam uji Box's M dan uji Levene's lebih dari 0,05 dan data tidak berasal dari populasi yang homogen jika signifikansi yang dihasilkan dalam uji Box's M dan uji Levene's kurang dari 0,05.

Uji korelasi dilakukan untuk mengetahui tingkat korelasi antara $Y_{1}$ (minat belajar siswa) dengan $\mathrm{Y}_{2}$ (prestasi belajar IPS). Pengujian dilakukan menggunakan uji product moment dengan taraf signifikansi $5 \%$. Bila hasil uji menunjukkan kedua variabel terikat tidak berkorelasi, maka analisis bisa dilanjutkan ke uji hipotesis dengan menggunakan analisis multivariant. Tetapi bila kedua variabel terikat $Y_{1}$ dan $Y_{2}$ berkorelasi, maka analisis untuk uji hipotesis dilanjutkan dengan menggunakan analisis lain.

Uji hipotesis digunakan uji F melalui MANOVA (Multvariate Analysis of Variance). Dalam hal ini digunakan bantuan SPSS-PC 17.0 for Windows. Kriteria pengujian: jika harga $F$ Wilks'Lambda menghasilkan angka signifikansi kurang dari 0,05 maka hipotesis nol ditolak dan dalam hal lain hipotesis nol diterima (Santosa, 2001:219).

\section{Hasil dan Pembahasan}

Deskripsi data dikelompokkan untuk menganalisis kecenderungan: (1) minat belajar yang mengikuti pembelajaran dengan menggunakan teknik klarifikasi nilai; (2) prestasi belajar yang mengikuti pembelajaran dengan menggunakan teknik klarifikasi nilai; (3) minat belajar yang mengikuti model pembelajaran konvensional; (4) prestasi belajar yang mengikuti model pembelajaran konvensional.

Tujuan penelitian merupakan urutan langkah yang pasti serta terarah terhadap sasaran penelitian. Tujuan pertama penelitian ini adalah untuk menguji pengaruh teknik klarifikasi nilai melawan model pembelajaran konvensional terhadap minat belajar siswa. Hasil uji hipotesis dalam penelitian ini terbukti bahwa: minat belajar siswa yang mengikuti teknik klarifikasi nilai (kelompok eksperimen) hasilnya lebih baik daripada minat belajar siswa yang mengikuti model pembelajaran konvensional (kelompok kontrol). Berdasarkan data hasil analisis multivariat dengan bantuan SPSS 17.00 for windows diperoleh nilai $F$ sebesar 60,474 , df $=1$, dan Sig = 0,000 . Ini berarti signifikansi lebih kecil dari 0,05 dapat ditarik simpulan bahwa terdapat 
perbedaan yang signifikan minat belajar antara siswa yang mengikuti pembelajaran teknik klarifikasi nilai dengan siswa yang mengikuti model pembelajaran konvensional.

Berdasarkan data hasil analisis tersebut, menurut Menurut Djahiri (1985) teknik pembelajaran VCT meliputi; percontohan, analisis nilai, daftar/matriks, kartu keyakinan, wawancara, yurisprudensi dan teknik inkuiri nilai.Selain itu dikenal juga dengan teknik klarikal nilai. Metode dan model di atas dianggap sangat cocok diterapkan dalam pembelajaran IPS, karena mata pelajaran IPS mengemban misi untuk membina nilai, moral, sikap dan prilaku siswa, disamping membina kecerdasan (knowledge) siswa. Djahiri juga menyatakan VCT (Value Clarification Technique) adalah suatu nama/label dari suatu model pendidikan nilai dari moral atau pendidikan afektif atauteknik pembelajaran yang mengembangkan kemampuan siswa mengidentifikasi dan menganalisis nilai-nilai yang termuat dalam suatu liputan peristiwa, lagu, tulisan, gambar, dan cerita rekaan.

Secara teoritis dapat dikatakan bahwa penggunaan teknik klarifikasi nilai lebih baik dan efektif untuk melibatkan minat belajar siswa dalam proses pembelajaran. Model ini memberikan ruang yang cukup untuk siswa mengkonstruksi pengetahuan, mengembangkan kemampuan yang dimiliki, bekerjasama dengan kelompoknya untuk berdiskusi, bebas memberikan pendapat, saling menghargai dan mengakui kelebihan teman-temannya, membangun suasana yang saling menjaga dan mendukung proses pembelajaran, serta menumbuhkan rasa memiliki.

Penelitian sejenis yang dilakukan Sucintia (2013), dalam artikelnya yang berjudul "Pengaruh Pembelajaran Teknik klarifikasi Nilai (TKN) terhadap Hasil Belajar Ditinjau dari Sikap Sosial Dalam Pembelajaran IPSPada Siswa Kelas VII SMP Negeri 4 Negara" menyatakan bahwa terdapat perbedaan yangsignifikan antara prestasi belajar IPS kelompok siswa yang mengikuti pembelajaran dengan modelTKN dan kelompok siswa yang mengikuti pembelajaran dengan konvensional, (2) terdapatpengaruh interaksi yang signifikan antara model TKN dan sikap sosial terhadap prestasi belajarIPS dan (3) untuk kelompok siswa yang memiliki sikap sosial tinggi dan rendah, terdapatperbedaan yang signifikan pada prestasi belajar IPS antara kelompok siswa yang mengikuti pembelajaran dengan TKN dan kelompok siswa yang mengikuti pembelajaran dengan konvensional.

Teknik klarifikasi nilai juga akan memungkinkan siswa dalam mengatur proses belajar dalam bentuk inisiatif diri, mandiri, pengaturan diri, eksplorasi diri dan kebebasan belajar untuk mencapai hasil belajar yang optimal. Dengan berbagai keunggulan yang dimiliki maka pendidikan dengan sistem pembelajaran dengan teknik klarifikasi nilai akan menjadi trend model pendidikan masa depan apabila terus dikembangkan, terutama dengan mengintegrasikan teknologi informasi dan komunikasi yang dewasa ini berkembang dengan pesat.

Pembelajaran teknik klarifikasi nilai (TKN) adalah suatu teknik pembelajaran yang memberikan siswa kesempatan untuk menganalisis dan klarifikasi nilai-nilai sebagaimana yang terjadi dalam kehidupan masyarakat. Manfaat implementasi TKN dapat membangkitkan siswa untuk belajar aktif, karena siswa diberikan kebebasan menganalisis dan klarifikasi nilai sekaligus bermain peran ini menuntut kerjasama dan sikap sosial antar siswa dalam memerankan dan menggambarkan suatu peristiwa yang tercipta dari kemampuan dalam menghayati dan menjiwai peran yang dilakoni oleh tiap anggota dalam kelompoknya. Sehingga meningkatkan sikap sosial siswa dalam pembelajaran PKn yaitu (1) toleransi, (2) kepedulian, (3) komunikatif, dan (4) kerjasama.

Sedangkan pembelajaran konvensional merupakan pembelajaran yang biasa dilakukan oleh guru dalam proses belajar mengajar di kelas. Pada pola pembelajaran konvensional, kegiatan proses belajar mengajar lebih sering diarahkan pada aliran informasi dari guru ke siswa atau dalam proses pembelajarannya hanya sekedar transfer ilmu dari guru kepada siswa saja, sehingga dalam pembelajaran model konvensional, kurang memperhatikan aspek sikap sosial atau interaksi sosial siswa, interaksi yang terjadi hanya satu arah saja, yaitu interaksi guru dan siswa. Untuk itu, perlu dibangun dan dilatih sikap social sedini mungkin kepada anak didik dengan penerapan implementasi TKN melalui bermain peran khususnya pada pelajaran Pendidikan Kewarganegaraan. Peserta didik mampu menghargai pendapat siswa lain, kerjasama dalam bermain peran dan tanggung jawab terhadap tugas yang diberikan. Kerangka berpikir di atas dapat digunakan dasar yang kuat untuk menduga bahwa minat siswa yang mengikuti pembelajaran TKN dengan pembelajaran konvensional berbeda secara signifikan pada mata pelajaran IPS kelas VI SD Gugus VI Kecamatan Sawan Kabupaten Buleleng. Maka dengan implementasi pembelajaran TKN dalam pembelajaran khususnya pada mata pelajaran IPS, dapat meningkatkan minat siswa dalam pembelajaran IPS. 
Tujuan penelitian yang kedua adalah menguji pengaruh teknik klarifikasi nilai versus model konvensional terhadap prestasi belajar IPS. Hasil uji hipotesis dalam penelitian ini terbukti bahwa: prestasi belajar IPS siswa yang mengikuti model pembelajaran teknik klarifikasi nilai (kelompok eksperimen) hasilnya lebih baik daripada prestasi belajar IPS siswa yang mengikuti model pembelajaran konvensional (kelompok kontrol). Berdasarkan data hasil penelitian analisis multivariate dengan berbantuan SPSS 17.00 for windows diperoleh nilai $\mathrm{F}$ sebesar 18,344, $\mathrm{df}=1$, dan $\mathrm{sig}=0,000$. Ini berarti nilai Sig lebih kecil dari 0,05 dapat ditarik kesimpulan bahwa terdapat perbedaan yang signifikan prestasi belajar IPS antara siswa yang mengikuti teknik klarifikasi nilai (kelas eksperimen) dengan siswa yang mengikuti model pembelajaran konvensional (kelas kontrol).

Melihat data hasil penelitian tersebut, Munandar (1999: 18) mengemukakan "Prestasi merupakan perwujudan dari bakat dan kemampuan".Belajar adalah kata kunci yang paling vital dalam setiap usaha pendidikan, sehingga tanpa belajar sesungguhnya tak pernah ada pendidikan. Sebagai suatu proses, belajar hampir selalu mendapat tempat yang luas dalam berbagai disiplin ilmu yang berkaitan dengan upaya kependidikan. Marhaeni (2011) mengemukakan bahwa "Belajar adalah proses perubahan menuju ke arah yang lebih baik". Sedangkan belajar menurut Sardiman (2011: 20) merupakan rangkaian kegiatan jiwa raga, psiko-fisik untuk menuju ke perkembangan pribadi manusia seutuhnya yang berarti menyangkut unsur cipta, rasa dan karsa, ranah kognitif, afektif dan psikomotorik.

Tujuan dari belajar yakni perubahan tingkah laku, hanya berbeda cara atau usaha pencapaiannya. Kegiatan belajar bertujuan untuk menghasilkan prestasi belajar. Menurut Djamarah (1994: 23) prestasi belajar adalah hasil yang diperoleh berupa kesan-kesan yang mengakibatkan perubahan dalam diri individu sebagai hasil dari aktivitas belajar. Sedangkan Syafir (2012) menyatakan bahwa "Prestasi belajar adalah segala sesuatu yang dicapai dimana prestasi itu menunjang kecakapan seorang manusia".

Implementasi pembelajaran TKN dalam pembelajaran IPS melibatkan siswa secara aktif, baik fisik maupun mental, sehingga akan membantu dan memudahkan siswa dalam memahami sebuah konsep selama proses dan setelah proses pembelajaran. Siswa diberikan kebebasan menganalisis nilai-nilai yang cocok dalam dirinya serta menerapkan nilai tersebut melalui bermain peran. Pengetahuan yang dibangun atau dikonstruksi sendiri oleh siswa melalui pengalamannya, akan menghasilkan pemahaman dan pengetahuan yang lebih tahan lama dan bermakna bagi siswa, hal tersebut juga dapat meningkatkan daya pikir kreatif dan kritis pada siswa sehingga dapat meningkatkan prestasi belajar siswa khususnya mata pelajaran IPS.

Pada proses pembelajaran konvensional, guru masih cenderung menjejali siswa dengan penghafalan materi, dan kurang memberi kesempatan siswa dalam menemukan dan mengembangkan pengetahuannya. Disamping itu, kreatifitas guru dalam menciptakan kondisi yang mengarahkan siswa agar mampu mengintegrasikan konstruksi pengalaman kehidupannya sehari-hari di luar kelas dengan konstruksi pengetahuannya di kelas kurang terlihat. Hal ini mengakibatkan siswa lebih banyak menghafalkan fakta dan konsep, sehingga pembelajaran IPS di sekolah dasar menjadi kurang menarik, membosankan, dan siswa terbiasa mengkonsumsi pengetahuan pada akhirnya siswa sulit mengkonstruksi pengetahuannya untuk berpikir kreatif dan kritis. Kesulitan tersebut juga berdampak pada tingkat prestasi belajar siswa yang menurun. Kerangka berpikir di atas dapat digunakan dasar yang kuat untuk menduga bahwa prestasi belajar IPS siswa yang mengikuti pembelajaran TKN dengan pembelajaran konvensional berbeda secara signifikan.

Secara teoritis dapat dikatakan bahwa prestasi belajar IPS siswa yang mengikuti teknik klarifikasi nilai lebih baik dan efektif. Satu diantara cara untuk mengetahui tingkat keberhasilan dalam suatu proses pembelajaran adalah dengan melihat prestasi belajar terhadap pelajaran IPS. Prestasi belajar merupakan sebuah kecakapan atau keberhasilan yang diperoleh seseorang setelah melakukan kegiatan dan proses belajar sehingga dirinya mengalami perubahan tingkah laku ke arah yang lebih baik. Perstasi belajar IPS yang dikaji dalam penelitian ini ditujukan pada domain kognitif. Dominasi satu diantara ranah akan membuat tidak utuhnya pencapaian tujuan pembelajaran, karena pembelajaran IPS itu sendiri Menurut Sudjana (2003: 4) adalah salah satu mata pelajaran yang dapat membentuk diri yang beragam dari segi agama, sosio-kultural, bahasa, usia, untuk menjadi warga negara yang cerdas, terampil dan berkarakter yang dilandasi oleh UUD 1945.

Temuan dalam penelitian ini sejalan dengan penelitian Okadana (2013) yang berjudul "Pengaruh Penerapan TKN Berbasis Asesmen Projek Terhadap Prestasi Belajar PKn Ditinjau Dari sikap Demokrasi Siswa Kelas VIII SMP N 2 Mengwi". Hasil penelitian menunjukkan bahwa: (1) prestasi belajar PKn siswa yang belajar dengan pembelajaran TKN berbasis asesmen 
projek lebih tinggi daripada yang belajar dengan model pembelajaran konvensional ( $F A=5,973$, $p<0,05),(2)$ terdapat pengaruh interaksi antara model pembelajaran dengan sikap demokrasi terhadap prestasi belajar PKn $(F A B=31,595, p<0,05)$, (3) siswa yang memiliki sikap demokrasi tinggi, prestasi belajar PKn yang belajar dengan pembelajaran TKN berbasis asesmen projek lebih tinggi daripada yang belajar dengan model konvensional (Qhitung= 8,02, $p<0,05$ ), (4) siswa yang memiliki sikap demokrasi rendah, prestasi belajar PKn yang belajar dengan model pembelajaran konvensional lebih tinggi daripada yang belajar dengan pembelajaran TKN berbasis asesmen projek(Qhitung=3,17, $p<0,05$ ).

Mengacu pada hal tersebut, terdapat perbedaan proses pembelajaran teknik klarifikasi nilai dengan model pembelajaran konvensional. Dengan adanya perbedaan pada proses pembelajaran, maka sangat memungkinkan jika prestasi belajar IPS siswa yang mengikuti pembelajaran dengan teknik klarifikasi nilailebih baik daripada prestasi belajar IPS siswa yang mengikuti model pembelajaran konvensional.

Penelitian yang ketiga bertujuan untuk mengetahui pengaruh teknik klarifikasi nilai secara simultan terhadap minat belajar dan prestasi belajar IPS Berdasarkan temuan ini maka hasil analisis MANOVA menunjukkan bahwa harga $\mathrm{F}$ hitung untuk Pillae Trace, Wilk Lambda, Hotelling's Trace, Roy's Largest Root dari implementasi teknik klarifikasi nilai lebih kecil dari 0,05. Artinya semua nilai Pillae Trace, Wilk Lambda, Hotelling's Trace, Roy's Largest Root signifikan. Dengan demikian, terdapat pengaruh penerapan teknik klarifikasi nilai terhadap minat belajar dan prestasi belajar IPS secara simultan pada siswa kelas VI SD Gugus VI Kecamatan Sawan Kabupaten Buleleng.

Temuan pada penelitian ini sejalan dengan hasil penelitian Sriwindari (2013) yang berjudul "Pengaruh Implementasi Pembelajaran Teknik Klarifikasi Nilai (TKN) Berbasis Multikultur Terhadap Minat belajar dan Prestasi Belajar IPS". Hasil penelitian menunjukkan bahwa : (1) Minat belajar siswa yang mengikuti pembelajaran TKN berbasis multikultur menunjukkan perbedaan yang signifikan dengan siswa yang mengikuti pembelajaran konvensional. Berdasarkan hasil perhitungan statistik yang dilakukan dengan uji anava satu jalur diperoleh Fhitung $=55,80$ dan hasil ini signifikan pada signifikansi 0,05 . (2) prestasi belajar IPS siswa yang mengikuti pembelajaran TKN berbasis multikultur menunjukkan perbedaan yang signifikan dengan siswa yang mengikuti pembelajaran konvensional. Berdasarkan hasil perhitungan statistik yang dilakukan dengan uji anava satu jalur diperoleh Fhitung $=41,33$ dan hasil ini signifikan pada signifikansi 0,05. (3) minat belajar dan prestasi belajar IPS siswa yang mengikuti pembelajaran TKN berbasis multikultur menunjukkan perbedaan yang signifikan dengan siswa yang mengikuti pembelajaran konvensional.

Pembelajaran teknik klarifikasi nilai (TKN) adalah suatu pembelajaran yang memberikan siswa kesempatan untuk menganalisis dan klarifikasi nilai-nilai sebagaimana yang terjadi dalam kehidupan masyarakat. Tujuan pembelajaran TKN dapat membangkitkan siswa untuk belajar aktif, karena siswa diberikan kebebasan menganalisis dan klarifikasi nilai serta menuntut kerjasama. Penerapan pembelajaran TKN pada pembelajaran IPS di sekolah dasar diharapkan dapat mengembalikan sebuah interaksi di kelas, dan dapat meningkatkan minat siswa terhadap pembelajaran IPS yang melibatkan anak secara langsung sehingga pembelajaran akan lebih bermakna dan meningkatkan prestasi belajar siswa. Pembelajaran konvensional merupakan pembelajaran yang paling sering dilakukan oleh guru-guru selama proses pembelajaran.

Dalam proses pembelajaran konvensional memiliki iklim sosial pada diri peserta didik dalam proses pembelajaran masih sangat minim, sehingga sikap sosial yang dimiliki anak masih sangat rendah dan kurang tampak dalam proses pembelajaran. Anak kurang melakukan komunikasi serta hubungan kerjasama dengan sesama siswa, sehingga di dalam proses pembelajaran yang dilakukan kurang mengembangkan sikap sosial yang ada pada diri siswa. Hal ini disebabkan karena guru masih cenderung mengajar dengan menggunakan metode ceramah, tanya jawab dan dalam proses pembelajaran guru hanya sekedar mentransfer ilmu kepada siswa saja. Hal ini mengakibatkan siswa lebih banyak menghafalkan fakta dan konsep tanpa melihat dan merasakan aplikasi yang ada dalam memecahkan masalah atau hal yang terjadi dilingkungannya, sehingga pembelajaran IPS di sekolah dasar menjadi kurang menarik, membosankan, dan siswa terbiasa mengkonsumsi pengetahuan pada akhirnya siswa sulit mengkonstruksi pengetahuannya untuk berpikir kreatif dan kritis. Kesulitan tersebut akan berdampak pada tingkat prestasi belajar siswa yang menurun. Kerangka berpikir di atas dapat digunakan dasar yang kuat untuk menduga bahwa minat dan prestasi belajar IPS siswa yang mengikuti pembelajaran TKN dengan pembelajaran konvensional berbeda secara signifikan. Pembelajaran TKN dapat meningkatkan minat siswa dengan siswa secara aktif, baik aktif fisik dan mental, juga akan membantu dan memudahkan siswa dalam memahami sebuah konsep 
selama proses dan setelah proses pembelajaran sehingga dapat berdampak pada meningkatnya prestasi belajar siswa.

Dengan demikian, minat belajar siswa dan prestasi belajar siswa yang mengikuti pembelajaran dengan teknik klarifikasi nilai lebih baik dibandingkan dengan minat belajar siswa dan prestasi belajar siswa yang mengikuti model pembelajaran konvensional. Pada dasarnya prestasi belajar adalah hasil dari suatu kegiatan yang telah dikerjakan, diciptakan, baik secara individual maupun kelompok (Djamarah,1994:19). Pada proses interaksi dalam pembelajaran siswa sebagai subjek didik melakukan perbuatan belajar yang ditandai dengan adanya perubahan tingkah laku pada dirinya atas adanya rangsangan dari lingkungan. Sedangkan pendapat lain menjelaskan belajar merupakan rangkaian kegiatan, jiwa raga, psikofisik menuju pada perkembangan pribadi manusia seutuhnya yang menyangkut unsure cipta, rasa, karsa ,ranah kognitif dan psikomotor. Aktivitas dari belajar secara rinci dan memiliki tujuan yang lebih luas yaitu perkembangan pribadi seutuhnya (Sardiman, 2003:38).

Mudjiono dan Dimyati (2006:239) juga mengatakan pengertian belajar adalah suatu proses aktif dalam memperoleh pengalaman/pengetahuan baru sehingga menyebabkan perubahan tingkah laku. Dengan demikian, belajar pada dasarnya merupakan suatu proses artinya kegiatan belajar senantiasa dinamis dan mengarah kepada terjadinya perubahan dalam diri peserta didik. Prestasi belajar dipengaruhi oleh faktor yang bersumber dari dalam diri siswa sebagai individu berupa usaha untuk mencapai keberhasilan dalam belajar. Motivasi berprestasi merupakan salah satu faktor yang berasal dari dalam diri siswa. Tanpa adanya motivasi, tidak mungkin siswa memiliki kamauan untuk belajar. Oleh karena itu, membangkitkan motivasi merupakan salah satu tugas guru dalam setiap proses pembelajaran. Selain itu juga dapat merangsang tumbuhnya rasa optimis sehingga akan dapat mendorong keinginan untuk bekerja maksimal akhirnya akan berujung pada peningkatan prestasi belajar. Keberhasilan yang dicapai akan menimbulkan perasaan dan sikap positif terhadap diri dan lingkungan, yang akhirnya akan menyebabkan timbulnya keinginan untuk mengerjakan tugas dengan sebaikbaiknya.

Pembelajaran IPS yang membosankan mengharuskan guru untuk menganti model pembelajaran yang digunakan agar tidak monoton. Ini berarti bahwa apabila mata pelajaran IPS dibelajarkan dengan cara yang tepat yaitu membuat pembelajaran yang menyenangkan maka materi akan lebih mudah dipahami siswa. Teknik klarifikasi nilai memiliki beberapa keunggulan jika dibandingkan dengan model pembelajaran konvensional yaitu pertama, mampu membina dan mempribadikan nilai dan moral; kedua, mampu mengklarifikasi dan mengungkapkan isi pesan materi yang disampaikan; ketiga mampu mengklarifikasi dan menilai kualitas nilai moral diri siswa dan nilai moral dalam kehidupan nyata; keempat, mampu mengundang, melibatkan, membina dan mengembangkan potensi diri siswa terutama potensi afektualnya; kelima, mampu memberikan pengalaman belajar dalam berbagai kehidupan; keenam, mampu menangkal, meniadakan mengintervensi dan menyubversi berbagai nilai moral naif yang ada dalam sistem nilai dan moral yang ada dalam diri seseorang; ketujuh, menuntun dan memotivasi untuk hidup layak dan bermoral tinggi. Sehingga dapat dikatakan bahwa teknik ini dapatmenyampaikan pesan-pesan kognitif dan afektif serta tepat digunakan pada materi pembelajaran IPS yang cenderung penuh dengan muatan moralitas, nilai-nilai pancasila dan norma yang berhubungan langsung dengan ungkapan sikap atau prilaku sebagai warga negara

Adanya korelasi langsung antara minat belajar dan prestasi belajar IPS, artinya semakin tinggi minat belajar siswa, semakin baik prestasi belajarnya. Agar proses pembelajaran efektif maka perlu melibatkan minat belajar, dengan minat belajarakan menghasilkan prestasi belajar yang baik atau bahkan lebih baik. Oleh karena itu, peran pendidik dalam hal ini harus berupaya membangkitkan minat belajar yang kuat pada diri siswa dengan menciptakan kesenangan dalam belajar.

Berdasarkan uraian tersebut, proses pembelajaran seyogyanya dipersiapkan dengan matang sehingga akan lebih efektif dan efisien yang tentunya akan berpengaruh pada minat belajar siswa. Pendidik juga memiliki peranan penting untuk memfasilitasi, membimbing dan membangkitkan minat belajar pada siswa sehingga menumbuhkan kecintaan untuk terus belajar khususnya mempelajari IPS. Teknik klarifikasi nilai mampu memenuhi apa yang dibutuhkan siswa selama pendidik selalu berupaya untuk merancang pembelajaran yang bermakna agar dapat meningkatkan minat belajar siswa dan dapat meningkatkan prestasi belajar IPS siswa. 
IVCEJ, Vol 1 No 1 , Tahun 2018

p-ISSN: 2615-4684 e-ISSN: 2615-6938

\section{Simpulan dan Saran}

Berdasarkan hasil pengujian hipotesis dan pembahasan hasil penelitian, maka dapat ditarik simpulan sebagai berikut.

Pertama, terdapat perbedaan minat belajar yang signifikan antara siswa yang mengikuti pembelajaran teknik klarifikasi nilai dengan rata-rata 133,2 dan siswa yang mengikuti model pembelajaran konvensional dengan rata-rata 116,775 Rata-rata minat belajar siswa yang mengikuti teknik klarifikasi nilai lebih tinggi dari minat belajar siswa yang mengikuti model pembelajaran konvensional.

Kedua, terdapat perbedaan prestasi belajar IPS yang signifikan antara siswa yang mengikuti pembelajaran teknik klarifikasi nilai dengan rata-rata 29,125 dan siswa yang mengikuti model pembelajaran konvensional dengan rata-rata 25,625. Rata-rata prestasi belajar IPS siswa yang mengikuti teknik klarifikasi nilai lebih tinggi dari prestasi belajar IPS siswa yang mengikuti model pembelajaran konvensional.

Ketiga, terdapat perbedaan minat belajar dan prestasi belajar IPS secara simultan antara siswa yang mengikuti teknik klarifikasi nilai dengan siswa yang mengikuti model pembelajaran konvensional. Minat belajar dan prestasi belajar IPS pada siswa yang mengikuti teknik klarifikasi nilai lebih tinggi dari siswa yang mengikuti model pembelajaran konvensional

Berdasarkan temuan-temuan tersebut dapat disimpulkan bahwa terdapat pengaruh implementasi teknik klarifikasi nilai terhadap minat belajar dan prestasi belajar IPS kelas VI SD Gugus VI Kecamatan Sawan Kabupaten Buleleng.

\section{Daftar Pustaka}

Converta. 2007. Metode Pengajaran Matematika Untuk Sekolah Dasar. Terjemahan Bambang Sumantri. Teaching Elementary School Matematics for Understannding.

Djamarah. Syaiful Bahri 1994. Prestasi Belajar dan Kompetensi Guru. Surabaya: Usaha Nasional.

Hamalik, Oemar. 1992. Psikologi Belajar Mengajar. Jakarta. Sinar Baru Algensindo.

Mulyana. 2004. Menjadi Guru Profesional Menciptakan Pembelajaran Kreatif dan Menyenangkan. Bandung: Rosda Karya.

Murtiningsih. 2004. Pengantar Kepada Membantu Guru Mengembangkan Kompetensinya dalam pegajaran Matematika. Jakarta: Dirjen Dikti.

Sardiman, A.M. 2003. Interaksi dan Motivasi Belajar Mengajar. Jakarta: PT. Raja Grafindo Persada.

Sindunata. 2001. Psikologi Pendidikan. Bandung:Remaja Rosda Karya.

Somantri, M. N. 2001. Menggagas Pembaharuan Pendidikan PKn. Bandung: Remaja Rosdakarya.

Sugiyono. 2006. Statistik Untuk Penelitian. Bandung Alfabeta.

Sumantri, M dan Johar Permana. 1999. Strategi Belajar Mengajar. Jakarta : Departemen Pendidikan dan Kebudayaan, Direkturat Jendral Pendidikan Tinggi, Proyek Pendidikan Guru Sekolah Dasar.

Suweni, N. N. 2011. Peningkatan Minat dan Hasil Belajar Matematika melalui Teknik klarifikasi nilai pada Siswa Kelas V SD No 1 Darmasaba Kecamatan Abiansemal Kabupaten Badung Tahun Pelajaran 2010/2011. Tesis (tidak diterbitkan). Singaraja: Program Pascasarjana Universitas Pendidikan Ganesha. 